\title{
A CONFIRMATORY FACTOR ANALYSIS FOR AN ADAPTED AND VALIDATED POLISH VERSION OF THE CHALDER FATIGUE QUESTIONNAIRE
}

\author{
AGATA ZDUN-RYŻEWSKA ${ }^{1}$, KRZYSZTOF BASIŃSKI ${ }^{1}$, and ANNA MICHALIK ${ }^{2}$
}

Medical University of Gdansk, Gdańsk, Poland

Faculty of Health Sciences

${ }^{1}$ Department of Quality of Life Research

${ }^{2}$ Department of Obstetric and Gynaecological Nursing

\begin{abstract}
Objectives: The Chalder Fatigue Questionnaire (CFQ) was developed to measure fatigue in 2 dimensions: physical and mental. The aim of the study was to translate, adapt and evaluate the psychometric properties of the Polish version of the CFQ (CFQ-PL). Material and Methods: The process of translation was conducted using a forward and backward translation procedure. After cultural adaptation, the psychometric properties of the CFQ-PL were evaluated. Participants of the study were healthy individuals: medical students $(\mathrm{N}=304)$ and pregnant women (pregnancy without complications, $\mathrm{N}=925$ ). The reliability and validity were estimated using fatigue numerical rating scales, the Beck Depression Inventory and the State-Trait Anxiety Inventory. To examine the factor structure of the CFQ-PL, a confirmatory factor analysis was conducted. Results: The internal consistency of the CFQ-PL was similar to the original version (Cronbach's $\alpha$ 0.85-0.91). Statistically significant correlations between the CFQ-PL and the current fatigue level, average fatigue and the sleepiness level (measured using numerical rating scales), as well as the intensity of depression and anxiety symptoms, all confirming the validity of the adapted scale. Using a confirmatory factor analysis, it was determined that a 1-factor model did not fit the data well. A 2-factor model with a correlation between mental and physical factors fitted better than the 1-factor model, yet fit indices revealed a poor fit. Using a 2-factor model with added covariance between items - 1 (problems with fatigue), 2 (resting more), 9 (slips of the tongue), 10 (finding the correct word) - resulted in acceptable fit indices in both groups of participants. Conclusions: After the process of translation, adaptation and validation of the CFQ-PL, it is now available for use under Polish conditions. This study provided evidence for structural validity of the 2-factor model of the 11-item version. Int J Occup Med Environ Health. 2020;33(1):67-76
\end{abstract}

Key words:

Chalder Fatigue Questionnaire, fatigue, validation, factor structure, confirmatory analysis, adaptation

\section{INTRODUCTION}

Fatigue is naturally connected with every human activity, both physical and mental, and is a complex phenomenon involved in both normal and problematic issues.

Many psychological and occupational medicine studies indicate the crucial significance of fatigue: the short-term impact on the ongoing performance of duties in the form of, for example, attention alteration or efficiency reduction (e.g., in the work of a driver, flight controller or a hospital staff member) [1]; the long-term impact related to "burnout" [2] and absences from work [3]. Increasing data indicate a growing problem with fatigue among students $[4,5]$.

Received: May 27, 2019. Accepted: October 18, 2019.

Corresponding author: Agata Zdun-Ryżewska, Medical University of Gdansk, Faculty of Health Sciences, Department of Quality of Life Research, Tuwima 15, 80-140 Gdańsk, Poland (e-mail: azdun@gumed.edu.pl). 
Fatigue is one of the main symptoms of chronic fatigue syndrome, whose prevalence is estimated at $0.1-3 \%$ in the general population, depending on the criteria used. Every primary care provider most likely faces at least 1 patient with fatigue on a weekly basis in everyday practice [6].

With the use of appropriate questionnaires, the detection and evaluation of elevated levels of fatigue allow the scale of the phenomenon to be estimated, and procedures to help those suffering from high levels of fatigue to be developed. One of the most popular scales to diagnose fatigue and tiredness, which has not yet been adapted to Polish conditions, is the Chalder Fatigue Questionnaire (CFQ) [7].

\section{Chalder Fatigue Questionnaire}

The CFQ was published in 1993 and was developed to measure the severity of fatigue in adults [8]. Primarily a 14-item instrument, it evolved into an 11-item instrument after adjustment and improvement. It reflects the multidimensional view of fatigue: decreased mental and physical endurance, fatigability, problems with thinking and memory. The subject answers the questions using a 4-step scale (choosing between "better than usual," "no more than usual," "worse than usual" and "much worse than usual"). Answers to the first 7 items give an insight into the intensity of the physical fatigue and the next 4 give a picture of the mental fatigue. The overall score is obtained by adding all the items. There are 2 scoring systems:

- a Likert system, where the subject's answers are evaluated by awarding $0,1,2$ or 3 pts, giving a maximum of 33 pts;

- a bimodal system, which ignores the severity of responses and categorizes the answers as a "problem" ("more than usual" and "much more than usual" $-1 \mathrm{pt}$ ) or "no problem" ("less than usual" and "no more than usual" - $0 \mathrm{pt}$ ), giving a maximum of $11 \mathrm{pts}$.

The survey procedure is extremely concise and can be finalized in about 3-5 min. The questionnaire is a type of a self-report measure (although it can also be used in the interview process) for the severity of fatigue in both clinical practice and research settings [9]. In the clinical field, it measures fatigue in different groups of patients, including in haemodialysis [10] or multiple sclerosis [11], but it can also be applied in the general population and in narrower groups of working populations, such as caregivers [12].

Currently, numerous adaptations have been completed, including a Brazilian version [13], a Japanese version [14], a Chinese version [15] and a Korean version [16]. Approval for the Polish adaptation was given by Trudie Chalder, the author of the CFQ. The final version of the CFQ-PL is attached as an appendix in the end of the article.

\section{Chalder Fatigue Questionnaire - Polish version - translation and cross-cultural adaptation}

During the first stage of the Polish adaption of the CFQ (CFQ-PL), a forward-backward translation procedure was conducted and translation correctness verification was made by a pilot group of participants. The forward-backward translation procedure was carried out in accordance with guidelines designed for the cross-cultural adaptation of health-related measures [17]. Four bilingual translators took part in the procedure (native English speakers who were fluent in the Polish language): 2 of them separately translated the questionnaire from English to Polish and during a conjoint meeting the final shape of the first Polish version was determined; then, the other 2 separately transcribed the first Polish version back to English. During the final meeting, the Committee Review Board, consisting of the 4 translators plus other researchers (a clinical psychologist and a methodologist - both fluent in the English language), compared both English adaptations and decided on the final form of the instrument. Due to the concise form of the questionnaire, there were no doubts about either translation or cultural adaptation. A hundred Polish students were asked to fill in and rate the questionnaire in a preliminary pilot study (pre- 
testing: filling in the form, measuring the time, marking any kind of difficulties or controversies) but as no crucial comments emerged, the questionnaire was deemed to be the final version.

To estimate the psychometric properties of the CFQ-PL, studies were carried out on a group of healthy individuals (medical university students and pregnant women).

\section{MATERIAL AND METHODS}

The 2 sample groups consisted of healthy individuals: medical students randomly selected from 2 universities in the same city ( $\mathrm{N}=304)$; and pregnant women recruited by midwifes and authors of the blog for future mothers (uncomplicated pregnancy, $\mathrm{N}=925$ ). The decision was made to choose 2 subject groups consisting of healthy, yet potentially fatigued, people. The majority of society consider medical studies as complex and the fatigue exhibited by medical students as something ordinary (non-pathological), simply connected to study requirements and a strict medical curriculum. According to various studies, the percentage of fatigued medical students in Poland fluctuates from $27 \%$ [18] up to $82 \%$ [19]. Also, in the group of pregnant and postpartum women fatigue is an evident and very often observed symptom [20]. Further studies using the CFQ-PL in various groups of patients would be useful for future research.

The sociodemographic characteristics of the 2 sample groups are shown in Table 1. All participants of the study were informed about the goal of the study and gave their consent to take part. The study design was evaluated positively by the local Bioethics Commission.

\section{Statistical analysis}

Descriptive statistics were used to describe the sociodemographic characteristics of the sample. Internal consistency of the CFQ-PL subscales was evaluated using Cronbach's $\alpha$. Pearson's product-moment correlation coefficients were computed to evaluate the associations between the CFQ-PL subscales and fatigue numerical rating scales, and the Beck Depression Inventory (BDI), also with the State-Trait Anxiety Inventory (STAI). To examine the factor structure of the CFQ-PL, a confirmatory factor analysis (CFA) was conducted. The authors tested a 1-factor model that constrains all the CFQ-PL items to a single construct (fatigue), as well as 2-factor solutions with latent factors: mental fatigue and physical fatigue. A 2-factor solution was suggested previously by the authors of the questionnaire. Model fit was evaluated using a $\chi^{2}$ test, the comparative fit

Table 1. English [8] and Polish versions of the Chalder Fatigue Questionnaire (CFQ)

\begin{tabular}{lll}
\hline Item & \multicolumn{1}{c}{ CFQ } & \multicolumn{1}{c}{ CFQ-PL } \\
\hline 1 & "Do you have problems with tiredness?" & Czy masz problemy ze zmęczeniem? \\
2 & "Do you need to rest more?" & Czy potrzebujesz więcej odpoczynku? \\
3 & "Do you feel sleepy or drowsy?” & Czy czujesz się niewyspany albo senny? \\
4 & "Do you have problems starting things?" & Czy masz problemy z rozpoczynaniem czynności? \\
5 & "Do you lack energy?" & Czy brakuje Ci energii? \\
6 & "Do you have less strength in your muscles?" & Czy masz mniej sily w mięśniach? \\
7 & "Do you feel weak?" & Czy czujesz się osłabiona/osłabiony? \\
8 & "Do you have difficulty concentrating?" & Czy trudno Ci się skoncentrować? \\
9 & "Do you make slips of the tongue when speaking?" & Czy zdarzają Ci się przejęzyczenia? \\
10 & "Do you find it more difficult to find the correct word?" & Czy jest Ci trudniej znajdować właściwe słowa? \\
11 & "How is your memory?" & Jak się sprawuje Twoja pamięć? \\
\hline
\end{tabular}


index (CFI), the Tucker-Lewis index (TLI), the root-meansquare error of approximation (RMSE) and the standardized root-mean-square residual (SRMR).

The model comparisons were based on fit indices. Criteria for acceptable model fit indices were based on Hooper et al. [21]. If a model showed a poor fit, modification was made using a modification index with the largest expected parameter change (as provided by lavaan). A hierarchical model was also evaluated, hypothesizing a higher-order fatigue factor that both mental and physical fatigue can be loaded into. All analyses were performed using R version 3.4.3 (R Core Team, 2017) with packages: dplyr for data manipulation [22] and lavaan for structural equation modeling [23].

\section{RESULTS}

\section{Reliability}

For the CFQ, internal consistency was estimated using Cronbach's $\alpha=0.88-0.90$ [24]. After translation and adaptation to Polish conditions, the CFQ-PL also received highly satisfactory Cronbach's $\alpha$ values, as shown in Table 2. Reliability, if any item was dropped, was always lower for the overall result of the questionnaire, ranging $0.82-0.84$ in the group of students and $0.89-0.90$ in the group of pregnant women.

\section{Validity}

The validity of the questionnaire was estimated using different scales and inventories for the different adaptations. For

Table 2. Characteristics of the group taking part in the study on translation, adaptation and evaluation of the psychometric properties of the Polish version of the Chalder Fatigue Questionnaire (CFQ-PL)

\begin{tabular}{|c|c|c|}
\hline \multirow{2}{*}{ Variable } & \multicolumn{2}{|c|}{$\begin{array}{l}\text { Participants } \\
(\mathrm{N}=1229)\end{array}$} \\
\hline & $\begin{array}{c}\text { students } \\
(\mathrm{N}=304)\end{array}$ & $\begin{array}{l}\text { pregnant women } \\
\qquad(\mathrm{N}=925)\end{array}$ \\
\hline Age [years] $(\mathrm{M} \pm \mathrm{SD})$ & $21 \pm 1.6$ & $30 \pm 3.9$ \\
\hline \multicolumn{3}{|l|}{$\operatorname{Sex}[\mathrm{n}(\%)]$} \\
\hline male & $106(35)$ & - \\
\hline female & $198(65)$ & $925(100)$ \\
\hline \multicolumn{3}{|l|}{ Education [n (\%)] } \\
\hline primary & & $5(0.5)$ \\
\hline vocational & & $6(0.6)$ \\
\hline secondary & & $95(9.5)$ \\
\hline college (or undergoing) & $304(100)$ & $818(82)$ \\
\hline \multicolumn{3}{|l|}{ Residence $[\mathrm{n}(\%)]$} \\
\hline city & $304(100)$ & $786(79)$ \\
\hline village & & $137(14)$ \\
\hline Gestational age [weeks] $(\mathrm{M} \pm \mathrm{SD})$ & - & $28.6 \pm 10.15$ \\
\hline \multicolumn{3}{|l|}{ Previous pregnancies $[\mathrm{n}(\%)]$} \\
\hline 0 & - & $332(36)$ \\
\hline $1-2$ & - & $510(55)$ \\
\hline$\geq 3$ & - & $79(8.5)$ \\
\hline
\end{tabular}


Table 3. Cronbach's $\alpha$ for the Polish version of the Chalder Fatigue Questionnaire (CFQ) in the study on translation, adaptation and evaluation of the psychometric properties of the Polish version of the CFQ (CFQ-PL)

\begin{tabular}{lccc}
\hline \multirow{2}{*}{\multicolumn{1}{c}{ Participants }} & \multicolumn{3}{c}{ CFQ Cronbach's $\alpha$} \\
\cline { 2 - 4 } & general result & physical fatigue dimension & mental fatigue dimension \\
\hline Students $(\mathrm{N}=304)$ & 0.85 & 0.84 & 0.73 \\
Pregnant women $(\mathrm{N}=925)$ & 0.91 & 0.9 & 0.87 \\
\hline
\end{tabular}

Table 4. Correlation in the student group $(\mathrm{N}=304)$ between the Chalder Fatigue Questionnaire (CFQ-PL) and the numerical rating scales (NRS) fatigue and sleepiness scale in the study on translation, adaptation and evaluation of the psychometric properties of the Polish version of the CFQ (CFQ-PL)

\begin{tabular}{lccc}
\hline & & \multicolumn{2}{c}{ Pearson's correlation } \\
\cline { 2 - 3 } & CFQ & fatigue & sleepiness \\
\cline { 2 - 3 } & at a given time & average & $0.44^{*}$ \\
\hline Physical & $0.38^{*}$ & $0.37^{*}$ & $0.32^{*}$ \\
Mental & $0.19^{*}$ & $0.22^{*}$ & $0.55^{*}$ \\
General & $0.45^{*}$ & $0.41^{*}$ & \\
\hline
\end{tabular}

* Statistical significance, $\mathrm{p}<0.05$.

example, in other research, the CFQ and the General Health Questionnaire (GHQ-12) are moderately correlated $(\mathrm{r}=0.62$, 95\% CI: 0.61-0.63) [25]. A positive correlation is observed between a questionnaire to measure fatigue and the Work and Social Adjustment Scale ( $\mathrm{r}=0.544, \mathrm{p}<0.0001)$ [24].

In this research, to measure the relevance of the CFQ-PL for the student group, numerical rating scales (NRS) were used to assess their current fatigue, average fatigue and sleepiness ( 0 - lack thereof, 10 - very substantial). These rating scales are widely used as a tool for screening fatigue measurement [26]. The results of correlations are shown in Table 3. Significant correlations between the CFQ-PL overall score, and sleepiness and perceived fatigue, simultaneously at a given time and on average, are worth emphasizing. This indicates a connection between the CFQPL result and these 3 measurements, which demonstrates a significant validity of the adapted questionnaire.

To explore the relevance of the instrument in the group of pregnant women, it was decided to use clinical scales, as shown in Table 4. The BDI was used to measure depression levels and has been applied for many years to assess the severity of depressive symptoms. To measure anxiety, the STAI (state anxiety variant) was applied. Usually, a greater intensity of fatigue accompanies intensified psychological distress. There is also a connection between the measurement of fatigue and the measurement of anxiety and depression, using various questionnaires for different study groups, including the general population [27,28]. Statistically significant correlations between the CFQ-PL overall score (taking its subscales into account as well) and the results of the BDI and STAI indicate a connection between these measurements.

\section{Factorial validity}

The results of CFA on the pregnant women are presented in Table 5. The 1-factor model (Model 1) did not fit the data very well $(\mathrm{CFI}=0.710 ; \mathrm{TLI}=0.638$; $\mathrm{RMSEA}=$ 0.213 , 90\% CI: 0.205-0.221; SRMR = 0.119). The 2-fac- 
Table 5. Correlation in the pregnant women group $(\mathrm{N}=925)$ between the Polish version of the Chalder Fatigue Questionnaire (CFQ-PL) and the Beck Depression Inventory (BDI), State-Trait Anxiety Inventory (STAI) (state) in the study on translation, adaptation and evaluation of the psychometric properties of the Polish version of the CFQ (CFQ-PL)

\begin{tabular}{|c|c|c|}
\hline \multirow{2}{*}{ CFQ } & \multicolumn{2}{|c|}{ Pearson's correlation } \\
\hline & BDI & STAI \\
\hline Physical & $0.55^{*}$ & $0.41^{*}$ \\
\hline Mental & $0.45^{*}$ & $0.43^{*}$ \\
\hline General & $0.58^{*}$ & $0.48^{*}$ \\
\hline
\end{tabular}

* Statistical significance, $\mathrm{p}<0.05$.

tor model with a correlation between mental and physical factors (Model 2) fitted better than Model 1, yet the fit indices revealed a poor fit $(\mathrm{CFI}=0.905$; $\mathrm{TLI}=0.879$; RMSEA $=0.123,90 \%$ CI: 0.115-0.132; SRMR $=0.084)$. Modification indices suggested 2 modifications of Model 2 that should significantly improve its fit. These were tested in Model 3 with covariance between items CHFQ1 ("Do you have problems with tiredness?") and CHFQ2 ("Do you need to rest more?"), as well as between items CHFQ9 ("Do you make slips of the tongue when speaking?") and CHFQ10 ("Do you find it more difficult to find the correct word?"). Model 3 fit indices ranged from acceptable $(\mathrm{TLI}=0.935$; RMSEA $=0.090,90 \%$ CI: 0.081$0.099 ;$ SRMR $=0.053)$ to good $(\mathrm{CFI}=0.952)$. A hierarchical model was also tested (Model 4), but its fit indices revealed a poor fit $(\mathrm{CFI}=0.905 ; \mathrm{TLI}=0.876$; $\mathrm{RMSEA}=$ 0.125, 90\% CI: 0.116-0.132; SRMR = 0.084).

The results of CFA on the group of students are presented in Table 6. Again, the 1-factor model (Model 5) did not fit the data well $(\mathrm{CFI}=0.753$; $\mathrm{TLI}=0.691$; RMEA $=$ 0.154, 90\% CI: 0.205-0.221; SRMR = 0.106). The 2-factor model with a correlation between mental and physical factors (Model 6) had better fit statistics than Model 5, yet it still indicated a poor fit $(\mathrm{CFI}=0.843$; $\mathrm{TLI}=0.799$; RMSEA $=0.125,90 \%$ CI: 0.110-0.139; SRMR $=0.085$ ). Modification indices suggested adding covariance between items CHFQ9 (slips of the tongue) and CHFQ10 (finding the correct word). In Model 7, the authors added this covariance, which resulted in acceptable fit indices $(\mathrm{CFI}=0.937$; TLI $=0.918 ; \mathrm{RMSEA}=0.079,90 \% \mathrm{CI}$ : 0.063-0.096; SRMR $=0.058$ ). They also tested a hierarchical model similar to Model 4 (Model 8), but again its fit indices revealed a poor fit $(\mathrm{CFI}=0.843$; $\mathrm{TLI}=$ $0.795 ;$ RMSEA $=0.126,90 \%$ CI: 0.111-0.141; SRMR $=$ $0.085)$.

\section{DISCUSSION}

The process of proper adaptation and validation of the CFQ-PL is extremely crucial and affects all results obtained in further studies. Rigorously following the guidelines for the translation procedure and the cross-cultural adaptation allowed the Polish version to be as reliable as the original version. The internal consistency of the CFQ-PL was similar to the original version (Cronbach's $\alpha 0.85-0.91$ ).

On the basis of the conducted research, it can also be acknowledged that the CFQ-PL is appropriately valid. Statistically significant correlations between the CFQ-PL and the current fatigue level, average fatigue and the sleepiness level (measured using numerical rating scales), as well as the intensity of depression and anxiety symptoms, all confirm the validity of the adapted scale. When reviewing the existing adaptations of the CFQ, the authors noticed that many correlations between fatigue, anxiety and depression were indicated [10,11,16,29]. Moreover, in this research significant correlations between the severity of 
Table 6. Confirmatory factor analysis of pregnant women and a group of students data (model fit statistics for competing 1-factor and 2-factor models) in the study on translation, adaptation and evaluation of the psychometric properties of the Polish version of the Chalder Fatigue Questionnaire (CFQ-PL)

\begin{tabular}{|c|c|c|c|c|c|c|c|c|c|}
\hline Group & Model & $\chi^{2}$ & Df & $\mathrm{p}$ & CFI & TLI & RMSEA & $\begin{array}{l}\text { RMSEA } \\
(90 \% \mathrm{CI})\end{array}$ & SRMR \\
\hline \multirow{4}{*}{$\begin{array}{c}\text { Pregnant } \\
\text { women }\end{array}$} & 1-factor model & 1888.72 & 44 & $<0.001$ & 0.710 & 0.638 & 0.213 & $0.205-0.221$ & 0.119 \\
\hline & $\begin{array}{l}\text { 2-factor model } \\
\text { with correlated factors }\end{array}$ & 646.117 & 43 & $<0.001$ & 0.905 & 0.879 & 0.123 & $0.115-0.132$ & 0.084 \\
\hline & $\begin{array}{l}\text { 2-factor model with covariance } \\
\text { (CHFQ1-2, CHFQ9-10) }\end{array}$ & 347.707 & 41 & $<0.001$ & 0.952 & 0.935 & 0.090 & $0.081-0.099$ & 0.053 \\
\hline & $\begin{array}{l}\text { hierarchical model with } \\
\text { higher-order fatigue factor }\end{array}$ & 646.117 & 42 & $<0.001$ & 0.905 & 0.876 & 0.125 & $0.116-0.133$ & 0.084 \\
\hline \multirow[t]{4}{*}{ Students } & 1-factor model & 362.638 & 44 & $<0.001$ & 0.753 & 0.691 & 0.154 & $0.139-0.168$ & 0.106 \\
\hline & $\begin{array}{l}\text { 2-factor model } \\
\text { with correlated factors }\end{array}$ & 245.817 & 43 & $<0.001$ & 0.843 & 0.799 & 0.124 & $0.109-0.139$ & 0.085 \\
\hline & $\begin{array}{l}\text { 2-factor model } \\
\text { with covariance (CHFQ9-10) }\end{array}$ & 123.316 & 42 & $<0.001$ & 0.937 & 0.918 & 0.079 & $0.063-0.096$ & 0.058 \\
\hline & $\begin{array}{l}\text { hierarchical with higher-order } \\
\text { fatigue factor }\end{array}$ & 244.415 & 42 & $<0.001$ & 0.843 & 0.795 & 0.126 & $0.111-0.141$ & 0.085 \\
\hline
\end{tabular}

CFI - comparative fit index; RMSEA - root mean square error of approximation index; SRMR - standardized root mean square residual; TLI - tucker lewis index.

depressive symptoms and the anxiety experienced at a given time were observed in the pregnant women. In turn, in the students, the research revealed correlations between the numerical rating scales, which are commonly used for screening fatigue [26], and the results of the adapted CFQ-PL.

Using a confirmatory factor analysis, it was determined that a 1-factor model did not fit the data well. A 2-factor model with a correlation between mental and physical factors fitted better than the 1-factor model, yet fit indices indicated a poor fit. Using a 2-factor model with added covariance between items - 1 (problems with fatigue), 2 (resting more), 9 (slips of tongue), 10 (finding correct word) - resulted in acceptable fit indices in both groups of participants.

In the original questionnaire [8], and in other adaptations as well [13], the authors obtained 2 principal components in the general population sample. In other publications, the original 2-factor model failed to fit the data even for the 11 -item version. During studies on healthy individuals in China, Fong, using exploratory structural equation modeling, suggested a 3 -factor structure consisting of physical fatigue ( 3 items), low energy (5 items) and mental fatigue (4 items).

In turn, Jing and Lin [30], also during studies on healthy China citizens, demonstrated that both the 2- and 3-factor models are appropriate. However, comparing the 2 models, the fit indices of the 3 -factor model were better. Interestingly, the authors advanced the notion of a completely different content for each factor: general feeling for fatigue (4 items), specific feeling for fatigue (6 items) and language difficulties (2 items). Similarly, as in the case of the 2 Chinese adaptations mentioned, an adaption conducted in Korea on a group of students exhibited a legiti- 
mate 3-factor model: physical fatigue ( 3 items), low energy (5 items) and mental fatigue (3 items) [16].

In turn, Chilcot et al. [11], during their study on a group of people suffering from multiple sclerosis, demonstrated a very different 2-factor model with 1 general fatigue factor incorporating 2 smaller group factors: mental and physical fatigue. An analogous 2-factor model with 1 general fatigue factor, but incorporating 3 smaller group factors (mental, physical and weakness), was proposed by Picariello who studied haemodialysis patients [10].

The authors of these adaptations themselves, pointing to possible explanations for such differences in results, often recall the cultural diversity phenomenon: the adaptations originate from different continents: Asia, Europe and South America. Fatigue perception in different cultures may vary, indicated by considering the significant subjectivism that accompanies its measurement.

Another reason for differences in the observed structure of the CFQ may be the selection of different groups of respondents recruited in various ways (including both healthy people and patients). Finally, the explanation may present itself in the differences in analytical methods.

In the most recent update of their own research, the authors of the CFQ, during the study of a group of healthy participants, as well as individuals suffering from chronic fatigue syndrome, again confirmed the presence of 2 components: physical and mental fatigue [25]. In both this research and the Polish adaption, the 2-factor model (physical and mental) with covariance between items 1 (problems with tiredness) and 2 (resting more), as well as between items 9 (slips of the tongue) and 10 (finding the correct word), is again the most suitable for this questionnaire.

\section{CONCLUSIONS}

The process of translation, adaptation and validation of the CFQ questionnaire allows the CFQ-PL to be considered as the final version and qualified to be used un- der Polish conditions. The questionnaire is concise and has satisfactory psychometric properties; furthermore, the CFQ-PL allows a final result to be obtained as well as results in 2 dimensions: physical and mental.

The limitation of the research is its use of only healthy individuals in the validation process. Further studies using the CFQ-PL in various groups of patients and in the general population would be useful for future research.

\section{REFERENCES}

1. Lal SKL, Craig A. A critical review of the psychophysiology of driver fatigue. Biol Psychol. 2001;55(2001):173-94, https:// doi.org/10.1016/S0301-0511(00)00085-5.

2. Workshops for the Helping Professions [Internet]. Kingston: Compassion Fatigue Solutions \& Professional Development; 2007 [cited 2019 Nov 7]. Running on Empty: Compassion Fatigue in Health Professionals. Available from: http://www. compassionfatigue.org/pages/RunningOnEmpty.pdf.

\section{Janssen N, Kant IJ, Swaen GMH, Janssen PPM, Schroer CAP.} Fatigue as a predictor of sickness absence: results from the Maastricht cohort study on fatigue at work. Occup Environ Med. 2003;60(Suppl I):71-6, https://doi.org/10.1136/oem.60. suppl_1.i71.

4. Tanaka M, Mizuno K, Fukuda S, Watanabe Y. Personality and Fatigue in Medical Students. Psychol Rep. 2010;106(2):56775, https://doi.org/10.2466/pr0.106.2.567-575.

5. Sievertsen HH, Gino F, Piovesan M. Cognitive fatigue influences students' performance on standardized tests. Proc Natl Acad Sci USA. 2016;113(10):2621-4, https://doi.org/10.1073/ pnas.1516947113.

6. Krupp LB. The Most Common Complaints: Fatigue. Butterworth-Heinemann; 2003.

7. Gawron VJ. Overview of Self-Reported Measures of Fatigue. Int J Aviat Psychol. 2016;26(34):120-31, https://doi.org/10.10 80/10508414.2017.1329627.

8. Chalder T, Berelowitz G, Pawlikowska T, Watts L, Wessely S, Wright D, et al. Development of a fatigue scale. J Psychosom Res. 1993;37(2):147-53. 
9. Shahid A, Wilkinson K, Marc S, Shapiro CM. STOP, THAT and One Hundred Other Sleep Scales. New York: SpringerVerlag; 2012. p. 97-8.

10. Picariello F, Moss-Morris R, Macdougall IC, Chilcot J. Measuring fatigue in haemodialysis patients: The factor structure of the Chalder Fatigue Questionnaire (CFQ). J Psychosom Res. 2016;(84):81-3, https://doi.org/10.1016/j.jpsychores. 2016.03.124.

11. Chilcot J, Norton S, Kelly ME, Moss-Morris R. The Chalder Fatigue Questionnaire is a valid and reliable measure of perceived fatigue severity in multiple sclerosis. Mult Scler. 2016;22(5):677-84, https://doi.org/10.1177/135245851 5598019.

12. Jackson C. The Chalder Fatigue Scale (CFQ 11). Occup Med (Lond). 2015;65(1):86, https://doi.org/10.1093/occmed/ kqu168.

13. Cho HJ, Costa E, Menezes PR, Chalder T, Bhugra D, Wessely S. Cross-cultural validation of the Chalder Fatigue Questionnaire in Brazilian primary care. J Psychosom Res. 2007;62(3):301-4, https://doi.org/10.1016/j.jpsychores. 2006.10.018.

14. Tanaka M, Fukuda S, Mizuno K, Imai-Matsumura K, Jodoi T, Kawatani J, et al. Reliability and validity of the Japanese version of the Chalder Fatigue Scale among youth in Japan. Psychol Rep. 2008;103(3):682-90, https://doi. org/10.2466/pr0.103.3.682-690.

15. Wong WS, Fielding R. Construct validity of the Chinese version of the Chalder Fatigue Scale in a Chinese community sample. J Psychosom Res. 2010;68(1):89-93, https://doi. org/10.1016/j.jpsychores.2009.05.008.

16. Ha H, Jeong D, Hahm B, Shim E. Cross-Cultural Validation of the Korean Version of the Chalder Fatigue Scale. Int J Behav Med. 2018;25(3):351-61, https://doi.org/10.1007/ s12529-017-9701-0.

17. Guillemin F, Bombardier C, Beaton DF. Cross-cultural adaptation of health-related quality of life measures. Literature review and proposed guidelines. J Clin Epidemiol. 1993;46(12): 1417-32, https://doi.org/10.1016/0895-4356(93)90142-N.
18. Łoza O. [Burnout syndrome among medical students: oneyear prospective study]. Psychiatria. 2016;13(4):224-8. Polish.

19. Pieniawska K, Śmiech K, Bar K, Pawlas K. [Can burnout manifest itself in college? A study of Polish medical students' population]. Med Środ. 2017;20(2):22-31, https://doi.org/ 10.19243/2017203. Polish.

20. Tsai SY, Shun SC, Lai YH, Lee YL, Lee SY. Psychometric evaluation of a Chinese version of the Lee Fatigue ScaleShort Form in women during pregnancy and postpartum. Int J Nurs Stud. 2014;51(7):1027-35, https://doi.org/10.1016/ j.ijnurstu.2013.10.023.

21. Hooper D, Coughlan J, Mullen MR. Structural equation modelling: Guidelines for determining model fit. Electron J Bus Res Meth. 2008;6(1):53-60.

22. Wickham H, Francois R, Henry L, Muller K. A Grammar of Data Manipulation. R package version 0.7.4. 2017.

23. Rossel Y. Lavaan: An R Package for Structural Equation Modeling. J Stat Softw. 2012;48:1-36, https://doi.org//10.18 637/jss.v048.i02.

24. Cella M, Chalder T. Measuring fatigue in clinical and community settings. J Psychosom Res. 2010;69(1):17-22, https:// doi.org/10.1016/j.jpsychores.2009.10.007.

25. Pawlikowska T, Chalder T, Hirsch SR, Wallace P, Wright DJM, Wessely SC. Population based study of fatigue and psychological distress. BMJ. 1994;308(6931):763-6, https://doi.org/ 10.1136/bmj.308.6931.763.

26. Minnock P, Kirwan J, Bresnihan B. Fatigue is a reliable, sensitive and unique outcome measure in rheumatoid arthritis. Rheumatology (Oxford). 2009;48(12):1533-6, https://doi.org/ 10.1093/rheumatology/kep287.

27. Watanabe N, Stewart R, Jenkins R, Bhugra DK, Furukawa TA. The epidemiology of chronic fatigue, physical illness, and symptoms of common mental disorders: A crosssectional survey from the second British National Survey of Psychiatric Morbidity. J Psychosom Res. 2008;64(4):357-62, https://doi.org/10.1016/j.jpsychores.2007.12.003.

28. Ter Wolbeek M, van Doornen LJP, Kavelaars A, TersteegKamperman MDJ, Heijnen CJ. Fatigue, depressive symptoms, 
and anxiety from adolescence up to young adulthood: A longitudinal study. Brain Behav Immun. 2011;25(6):1249-55, https://doi.org/10.1016/j.bbi.2011.04.015.

29. Fong TCT, Chan JSM, Chan CLW, Ho RTH, Ziea ETC, Wong VCW, et al. Psychometric properties of the Chalder Fatigue Scale revisited: an exploratory structural equation modeling approach. Qual Life Res. 2015;24(9):2273-78, https://doi.org/10.1007/s11136-015-0944-4.
30. Jing MJ, Lin WQ, Wang Q, Wang JJ, Tang J, Jiang ES, et al. Reliability and construct validity of two versions of Chalder fatigue scale among the general population in mainland China. Int J Env Res Public Health. 2016;13(1):147, https:// doi.org/10.3390/ijerph13010147.

Appendix. Chalder Fatigue Questionnaire - PL (polska adaptacja: Agata Zdun-Ryżewska, Krzysztof Basiński, Anna Michalik) Chcielibyśmy dowiedzieć się więcej o wszelkich problemach, jakie miałaś/miałeś z uczuciem zmęczenia, osłabienia albo braku energii w ciągu ostatniego miesiąca. Odpowiedz na WSZYSTKIE pytania, zaznaczając odpowiedź, która najbardziej Cię dotyczy. Jeśli czujesz się zmęczona/zmęczony od dawna, porównaj swój stan do tego, kiedy ostatnio czułaś/czułeś się dobrze. Zaznacz tylko jedno pole w każdym wierszu.

\begin{tabular}{cccc}
\hline Mniej & Nie więcej & Więcej \\
niż zwykle & niż zwykle & niż zwykle & $\begin{array}{c}\text { Znacznie więcej } \\
\text { niż zwykle }\end{array}$ \\
\hline
\end{tabular}

Czy masz problemy ze zmęczeniem?

Czy potrzebujesz więcej odpoczynku?

Czy czujesz się niewyspany albo senny?

Czy masz problemy z rozpoczynaniem czynności?

Czy brakuje Ci energii?

Czy masz mniej siły w mięśniach?

Czy czujesz się osłabiona / osłabiony?

Czy trudno Ci się skoncentrować?

Czy zdarzają Ci się przejęzyczenia?

Czy jest Ci trudniej znajdować właściwe słowa?

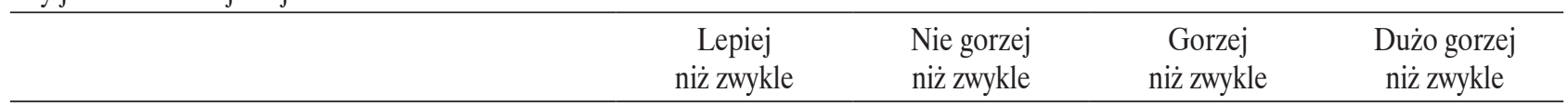

Jak się sprawuje Twoja pamięć?

This work is available in Open Access model and licensed under a Creative Commons Attribution-NonCommercial 3.0 Poland License - http://creativecommons.org/ licenses/by-nc/3.0/pl/deed.en. 